\title{
Relationship between Amino Acid Composition of Diet and Plasma Cholesterol Level in Growing Rats Fed a High Cholesterol Diet
}

\author{
Kimio SugiYama, Setsuko OHKAWA, and \\ Keiichiro MURAMATSU ${ }^{1}$ \\ Laboratory of Food and Nutrition, Department of Agricultural \\ Chemistry, Faculty of Agriculture, Shizuoka \\ University, Ohya, Shizuoka 422, Japan \\ (Received March 15, 1986)
}

\begin{abstract}
Summary The effects of dietary sulfur-containing amino acids and glycine on plasma cholesterol level were studied in rats fed amino acid mixture diets containing cholesterol. The relationship between the amino acid composition of dietary proteins and plasma cholesterol levels was also investigated in rats fed diets containing various kinds of protein such as casein, egg albumin, pork protein, fish protein, corn gluten, wheat gluten and soy protein. Feeding the amino acid mixture corresponding to casein led to an approximately two-fold level of plasma total cholesterol as compared with feeding the amino acid mixture corresponding to wheat gluten. It was possible to reduce the plasma cholesterol of rats fed the amino acid mixture of the casein type by increasing the proportion of cystine in the total sulfur amino acids. Inversely, the deprivation of cystine resulted in an enhancement of the plasma cholesterol of rats fed the gluten type amino acid mixture. Glycine had a tendency to resist increases in the plasma cholesterol level. A significant negative correlation was noted between plasma cholesterol levels and the content of cystine in intact dietary proteins. The results suggest that the differential effect of dietary proteins on plasma cholesterol level is mainly associated with sulfurcontaining amino acids included in the protein, regardless of whether it is of animal or plant origin.
\end{abstract}

Key Words plasma cholesterol, amino acid composition, methionine, cystine, glycine, dietary protein

The plasma cholesterol concentration has been shown to be affected by dietary proteins as well as other dietary components in experimental animals and humans(1-4). Although the mechanism by which dietary protein influences the plasma cholesterol level is not yet fully understood, it is probable that specific amino

1 杉山公男, 大川勢津子, 村松敬一郎 
acids or amino acid compositions are relevant to the influence of the protein $(2,5-7)$.

Previously we offered some evidence for the possible importance of dietary sulfur-containing amino acids and glycine in the regulation of plasma cholesterol level in rats fed a high cholesterol $\operatorname{diet}(8,9)$. Furthermore, the property of a diet containing an amino acid mixture resembling casein or wheat gluten could be modified by changing the amino acid contents of only three amino acids, i.e., methionine, cystine and glycine (10). These results suggest that the effect of dietary protein on the plasma cholesterol level is elicited by specific amino acids, at least in rats fed a high cholesterol diet.

The present study was designed: 1) to obtain further insight into the contribution of methionine, cystine and glycine to plasma cholesterol regulation in the rat using amino acid mixture diets, and 2) to know the relationship, if any, between the content of each amino acid of dietary proteins and the plasma cholesterol level, using intact proteins of various animal and plant origins.

\section{MATERIALS AND METHODS}

Male albino Wistar strain rats weighing about $80 \mathrm{~g}$ were used. The animals were individually housed in suspended wire cages in a temperature-controlled $\left(24^{\circ} \mathrm{C}\right)$ room operated on a 12 -h cycle of light $(06: 00$ to $18: 00)$ and dark. The animals were fed experimental diets ad libitum for two or three weeks. The composition of the basal ( $25 \%$ casein) diet was as follows (\%): casein, 25 ; sucrose, 15; lard, 15; corn oil, 2; salt mixture, 5(11); vitamin mixture, 1 (11); choline chloride, 0.2 ; cholesterol, 1; sodium cholate, 0.25 ; and corn starch to $100 \%$. The basal diet also contained 2,700 IU vitamin A, $230 \mathrm{IU}$ vitamin $\mathrm{D}_{3}$ and $12 \mathrm{mg}$ vitamin $\mathrm{E}$ per $100 \mathrm{~g}$. In experimental diets, casein was replaced by other protein or amino acid mixtures (all L-isomers, supplied by Ajinomoto Co., Ltd., Tokyo) of an approximately equivalent level of nitrogen to $25 \%$ casein. The diets containing amino acid mixture were supplemented with zinc chloride and sodium selenite according to Ebihara et al. (12). At the end of the feeding period, food was removed at 24:00, and animals were sacrificed to obtain blood plasma and liver between 11:00 and $12: 00$ on the next day.

Experiment 1. Rats were fed diets containing $25 \%$ casein, wheat gluten or amino acid mixture simulating casein or wheat gluten with or without modification of the amino acid composition for 2 weeks. The diets containing wheat gluten and its simulating amino acid mixture were fortified with $0.7 \%$ lysine $\cdot \mathrm{HCl}$.

Experiment 2. Rats were fed diets containing one of various proteins such as casein, egg albumin, pork protein, cod protein, corn gluten, wheat gluten and soy protein for 3 weeks. The diets containing corn gluten and wheat gluten were fortified with lysine $\cdot \mathrm{HCl}$ at levels of 0.5 and $0.7 \%$, respectively. Pork protein and cod protein were prepared from pork and cod minces by the extraction of lipids with ether followed by freeze-drying. The other proteins were obtained commercially. 
The purities of proteins used were $95,85,91,90,75,83$ and $85 \%$ for casein, egg albumin, pork protein, cod protein, corn gluten, wheat gluten and soy protein, respectively.

The total liver lipids were extracted by the method of Folch et al.(13) and measured gravimetrically. The total cholesterol concentration of plasma and liver was measured by the method of Zak (14). High density lipoprotein (HDL) was separated by the heparin- $\mathrm{Mn}^{2+}$ precipitation method (15) followed by the enzymatic measurement of HDL-cholesterol with a commercial kit (Wako Pure Chemical Ind., Osaka). Plasma triglycerides was measured enzymatically with a commercial kit (Wako Pure Chemical Ind., Osaka).

Experimental data were analyzed statistically by using one-way analysis of variance, and correlation coefficients were also determined(16).

\section{RESULTS}

\section{Influence of dietary sulfur amino acids and glycine on plasma cholesterol}

Table 1 shows the growth, food intake and liver weight of rats fed diets containing casein, wheat gluten or amino acid mixture simulating casein or wheat gluten with or without modification of the content of methionine, cystine and/or glycine. The body weight gains of animals fed amino acid mixture diets were generally smaller than those fed intact protein diets. When a large portion of methionine was replaced by cystine in casein-simulating amino acid mixtures, growth and food intake were depressed and liver size was enlarged, possibly due to methionine deficiency. There was no significant difference in growth and food intake among groups in gluten-simulating amino acid mixtures, irrespective of the modification of amino acid composition.

Plasma and liver lipid concentrations are summarized in Table 2. The plasma cholesterol levels of rats fed diets containing wheat gluten and its amino acid mixture were about half of rats fed diets containing casein and its amino acid mixture. When cystine content was increased at the expense of methionine in caseinsimulating amino acid mixtures, the concentration of plasma total cholesterol decreased significantly. The addition of $2.5 \%$ glycine had a tendency to lower the plasma cholesterol although no statistically significant difference was observed. When the diet was deprived of cystine, on the other hand, the plasma total cholesterol level was significantly enhanced in gluten-simulating amino acid mixture diets. Glycine deprivation also had a tendency to enhance plasma cholesterol level although no statistically significant difference was observed. The proportion of HDL-cholesterol to the plasma total cholesterol was generally elevated in the groups with low plasma total cholesterol levels. In casein-simulating amino acid mixture diets, a lowering of methionine content led to a reduction of liver cholesterol and to a tendency for liver total lipids to increase. 


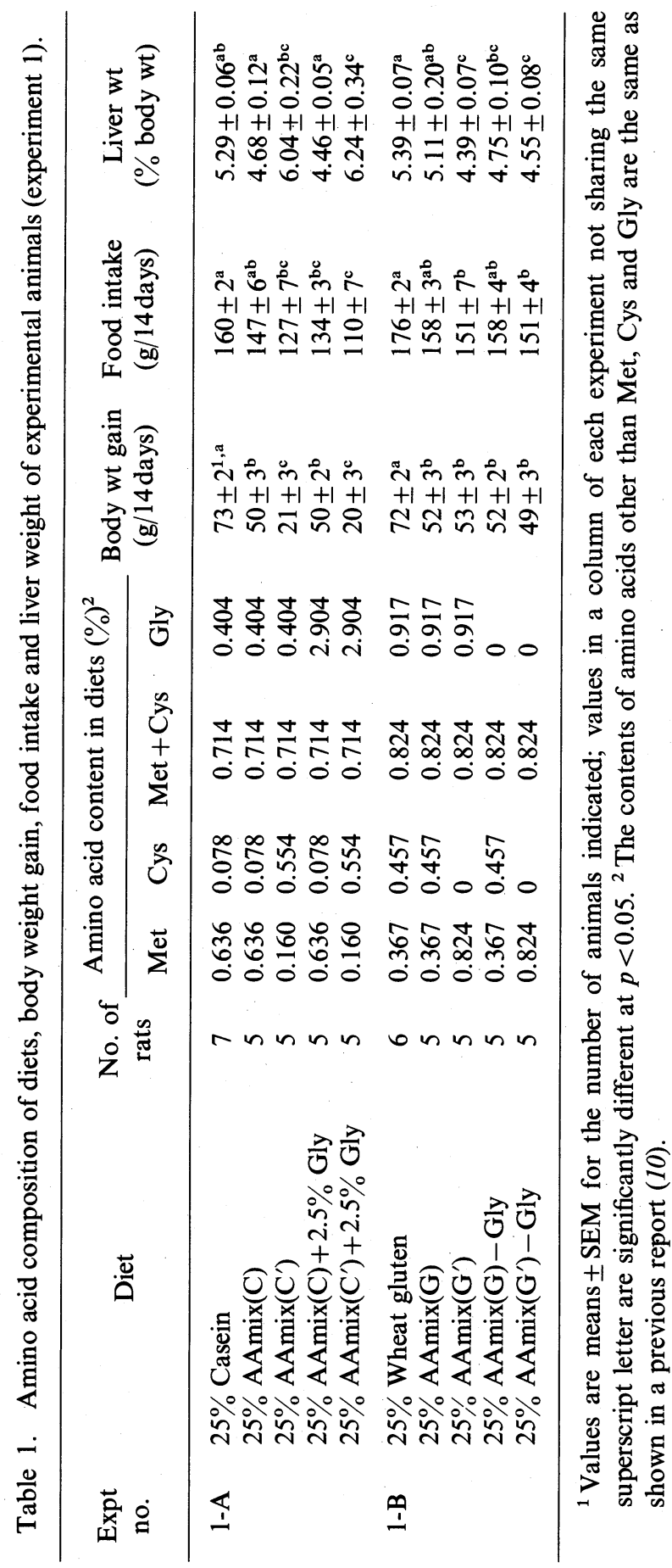




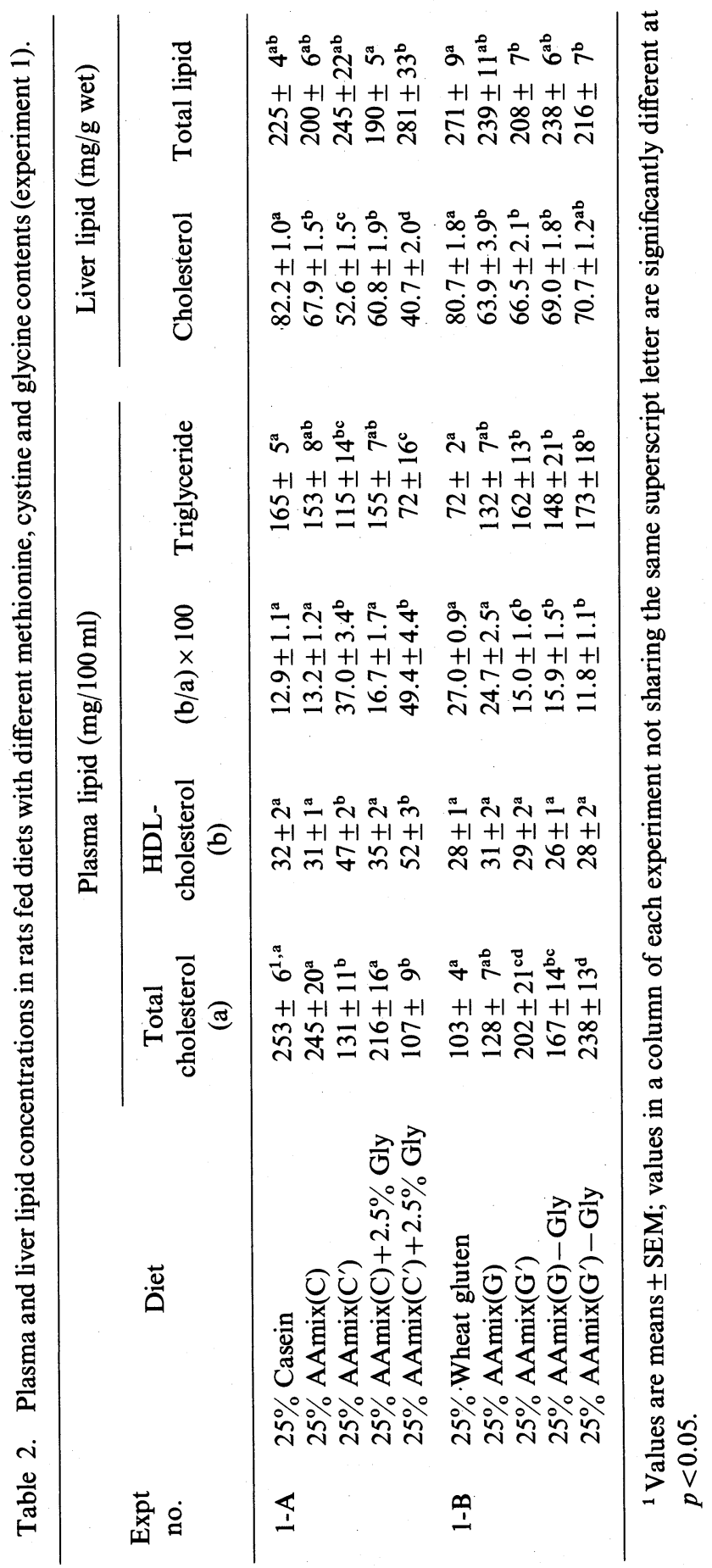




\section{Effects of various dietary proteins on plasma cholesterol}

The growth, food intake, plasma and liver lipid concentrations of rats fed diets containing various kinds of protein are shown in Tables 3 and 4 . The growth of animals fed egg albumin and corn gluten was slightly depressed as compared with the other groups. As a whole, the feeding of plant proteins resulted in lower levels of plasma total cholesterol as compared with animal proteins except for egg albumin. The proportion of HDL-cholesterol to the total cholesterol was apparently higher

Table 3. Body weight gain, food intake and liver weight of rats fed different dietary proteins (experiment 2).

\begin{tabular}{lcccc}
\hline \multicolumn{1}{c}{ Diet } & $\begin{array}{c}\text { No. of } \\
\text { rats }\end{array}$ & $\begin{array}{c}\text { Body wt gain } \\
(\mathrm{g} / 21 \text { days })\end{array}$ & $\begin{array}{c}\text { Food intake } \\
(\mathrm{g} / 21 \text { days })\end{array}$ & $\begin{array}{c}\text { Liver wt } \\
(\% \text { body wt })\end{array}$ \\
\hline $25 \%$ Milk casein & 6 & $107 \pm 4^{1, \mathrm{ab}}$ & $251 \pm 5^{\mathrm{ac}}$ & $5.78 \pm 0.11^{\mathrm{a}}$ \\
$25 \%$ Egg albumin & 6 & $89 \pm 2^{\mathrm{ac}}$ & $214 \pm 4^{\mathrm{b}}$ & $4.72 \pm 0.10^{\mathrm{b}}$ \\
$25 \%$ Pork protein & 5 & $114 \pm 2^{\mathrm{b}}$ & $251 \pm 5^{\mathrm{ac}}$ & $5.12 \pm 0.09^{\mathrm{bc}}$ \\
$25 \%$ Cod protein & 5 & $111 \pm 3^{\mathrm{b}}$ & $238 \pm 4^{\mathrm{ab}}$ & $5.49 \pm 0.13^{\mathrm{ac}}$ \\
$25 \%$ Corn gluten & 5 & $86 \pm 7^{\mathrm{c}}$ & $259 \pm 14^{\mathrm{ac}}$ & $4.96 \pm 0.15^{\mathrm{bc}}$ \\
$25 \%$ Wheat gluten & 5 & $101 \pm 3^{\mathrm{abc}}$ & $244 \pm 9^{\mathrm{abc}}$ & $5.54 \pm 0.17^{\mathrm{ac}}$ \\
$25 \%$ Soy protein & 5 & $108 \pm 3^{\mathrm{ab}}$ & $280 \pm 5^{\mathrm{c}}$ & $4.89 \pm 0.08^{\mathrm{bc}}$ \\
\hline
\end{tabular}

${ }^{1}$ Values are means \pm SEM for the number of animals indicated; values in a column not sharing the same superscript letter are significantly different at $p<0.05$.

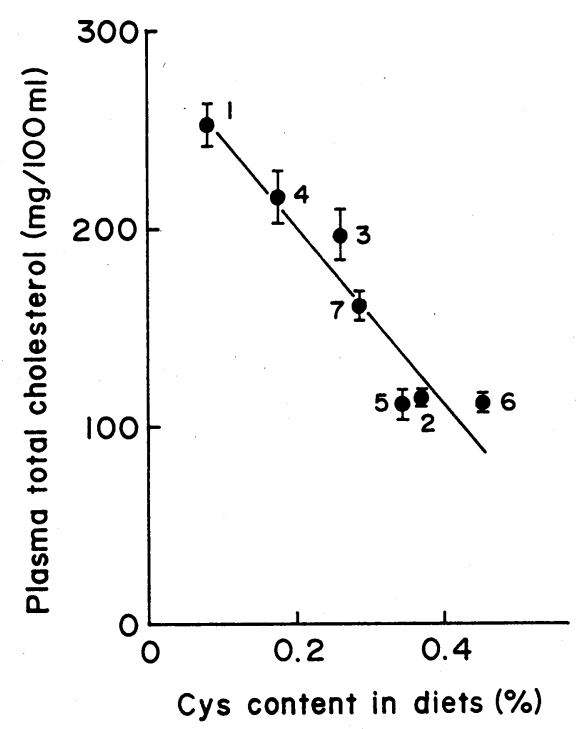

Fig. 1. Relationship between cystine content in diets and plasma cholesterol levels in rats fed diets containing different proteins. The numbers denote the following protein groups: 1 , casein; 2 , egg albumin; 3 , pork protein; 4 , cod protein; 5 , corn gluten; 6 , wheat gluten; and 7 , soy protein. 


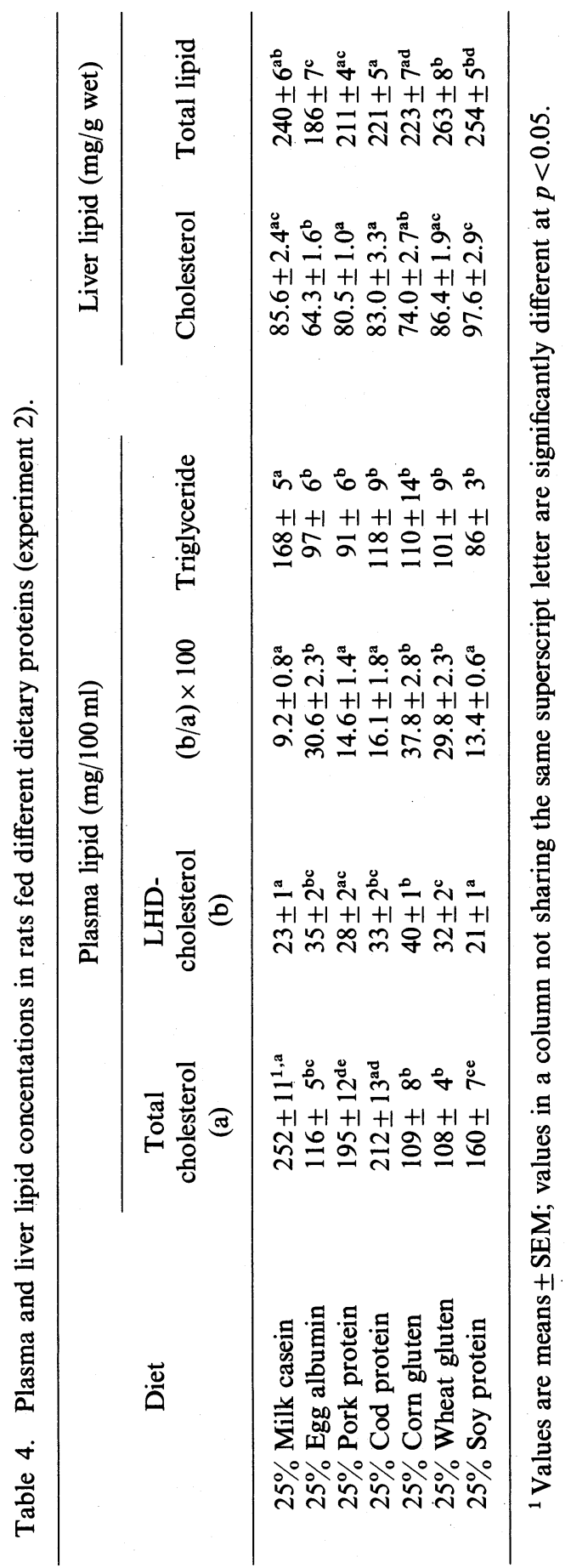


Table 5. Correlation between amino acid content in diets and plasma cholesterol concentration.

\begin{tabular}{lrrlrr}
\hline Amino acid & $r^{1}$ & $p$ & Amino acid & $r$ & $p$ \\
\hline Cys & -0.94 & $<0.01$ & Met +Cys & -0.26 & NS \\
Lys & 0.73 & NS $^{2}$ & Glu & -0.25 & NS \\
Tyr & 0.58 & NS & Met & 0.20 & NS \\
Thr & 0.53 & NS & Leu & -0.18 & NS \\
Trp & 0.52 & NS & Asp & -0.15 & NS \\
His & 0.44 & NS & Ser & -0.13 & NS \\
Phe & -0.41 & NS & Val & 0.11 & NS \\
Ala & -0.34 & NS & Arg & 0.10 & NS \\
Ile & 0.30 & NS & Pro & 0.02 & NS \\
Gly & -0.30 & NS & & & \\
\hline
\end{tabular}

${ }^{1}$ Correlation coefficient. ${ }^{2}$ Not significant.

in groups with lower plasma total cholesterol levels. Plasma triglyceride concentration was higher in casein-fed rats than in other groups. The contents of cholesterol and total lipid in the liver did not show obvious change either proportional or inversely proportional to the change in plasma cholesterol level.

Table 5 shows the relationship between plasma total cholesterol levels and the content of each amino acid in dietary proteins. Correlation coefficients were obtained using mean values of the plasma total cholesterol level of each group and published data on the amino acid composition for pork protein and cod protein (17) and for the other proteins used(18). A significant correlation was detected only between plasma total cholesterol levels and the cystine content of proteins. As illustrated in Fig. 1, the results indicate that the plasma total cholesterol apparently decreases as the cystine content in the diet increases.

\section{DISCUSSION}

Several different explanations have been offered to account for the different effects of dietary proteins on plasma cholesterol levels, e.g., amino acid composition(2,5-7), digestibility(19-23) and minor components attached to protein (24). However, it appears that conclusive results have not yet been obtained. Our results obtained here support the notion that specific amino acids are responsible for the effect of dietary proteins, at least under the experimental conditions used. The results of experiment 1 indicate that a diet high in methionine and low in cystine leads to a higher plasma cholesterol level, and that a diet low in methionine and high in cystine inversely leads to a lower plasma cholesterol level, although it is impossible to ascertain from this experiment whether methionine or cystine is more crucial in this effect. Dietary glycine also appears to have some effect. Thus, it is clear from present and previous (10) reports on rats fed amino acid 
mixture diets that sulfur-containing amino acids and probably glycine in the diet can influence the plasma cholesterol level. These effects of specific amino acids are not, however, unexpected since it has been reported that the plasma cholesterol level was increased by the dietary addition of methionine $(1,8,9)$ and was decreased by the addition of cystine $(8,9,25,26)$, glycine $(9,27)$ or methionine plus glycine $(9)$ in rats fed a cholesterol-containing diet.

In rats fed diets containing various kinds of intact proteins, on the other hand, the plasma cholesterol level had a significant negative correlation with the cystine content of dietary proteins, but not with other amino acids (experiment 2). This partially supports previous results by Sautier et al. (28); they showed that serum cholesterol levels in rats fed cholesterol-free diets containing casein, whey protein, soy protein and sunflower protein had a significant positive correlation with tyrosine and glutamic acid, and a negative correlation with cystine and alanine, and suggested that the effect of dietary proteins on serum total and HDL-cholesterol level could be related to the ratio of (tyrosine + glutamic acid): (cystine+alanine). Although it has been noticed that animal proteins, as compared with plant proteins, have a tendency to contain higher levels of methionine(29), it might also be necessary to take into consideration the fact that plant proteins generally contain relatively higher levels of cystine as shown in Fig. 1. It is of interest in this connection that some types of animal protein such as egg albumin and whey protein (28) contain higher levels of cystine and that these proteins have a serum or plasma cholesterol-lowering effect despite their animal origin. Sautier et al.(28) have already noted that the hypocholesterolemic effect of dietary protein is not always related to plant origin, on the basis of the fact that whey protein has a cholesterol-lowering effect. Furthermore, Jenkins et al. $(30,31)$ also have presented evidence showing that animal proteins do not necessarily lead to a higher plasma cholesterol level compared with plant proteins. Thus, it is evident that the effect of dietary proteins cannot be fully explained on the basis of the classification of proteins by animal or plant origin. The results obtained in the present study prompted us to propose that dietary proteins might be roughly classified with respect to plasma cholesterol regulation in rats as cystine-rich and cystine-deficient proteins, regardless of their origin. This does not, however, exclude the importance of methionine and probably glycine contents as shown in experiment 1 with amino acid mixture diets. Further studies are needed to test the above hypothesis.

\section{REFERENCES}

1) Carroll, K. K., and Hamilton, R. M. G. (1975): Effect of dietary protein and carbohydrate on plasma cholesterol in relation to atherosclerosis. J. Food Sci., 40, 18-23.

2) Kritchevsky, D. (1979): Vegetable protein and atherosclerosis. J. Am. Oil Chem. Soc., 56, 135-140.

3) Gibney, M. J. (1982): Hypocholesterolemic effect of soya-bean proteins. Proc. Nutr. Soc., 41, 19-26.

Vol. 32, No. 4, 1986 
4) Sirtori, C. R., Gatti, E., Mantero, O., Conti, F., Agradi, E., Tremoli, E., Sirtori, M., Fraterrigo, L., Tavazzi, L., and Kritchevsky, D. (1979): Clinical experience with soybean protein diet in the treatment of hypercholesterolemia. Am. J. Clin. Nutr., 32, 1645-1658.

5) Huff, M. W., Hamilton, R. M. G., and Carroll, K. K. (1977): Plasma cholesterol levels in rabbits fed low fat, cholesterol-free, semipurified diets: effects of dietary proteins, protein hydrolysates and amino acid mixtures. Atherosclerosis, 28, 187-195.

6) Yadav, N. R., and Liener, I. E. (1977): Reduction of serum cholesterol in rats fed vegetable protein or an equivalent amino acid mixture. Nutr. Rep. Int., 16, 385-389.

7) Sugano, M. (1983): Hypocholesterolemic effect of plant protein in relation to animal protein: mechanism of action, in Animal and Vegetable Proteins in Lipid Metabolism and Atherosclerosis, ed. by Gibney, M. J., and Kritchevsky, D., Alan R. Liss Inc., New York, pp. 51-81.

8) Sugiyama, K., Kushima, Y., and Muramatsu, K. (1984): Effect of methionine, cystine and taurine on plasma cholesterol level in rats fed a high cholesterol diet. Agric. Biol. Chem., 48, 2897-2899.

9) Sugiyama, K., Kushima, Y., and Muramatsu, K. (1985): Effects of sulfur-containing amino acids and glycine on plasma cholesterol level in rats fed on a high cholesterol diet. Agric. Biol. Chem., 49, 3455-3461.

10) Sugiyama, K., Ozawa, M., and Muramatsu, K. (1985): Dietary sulfur-containing amino acids and glycine as determinant factors in plasma cholesterol regulation in growing rats. J. Nutr. Sci. Vitaminol., 31, 121-125.

11) Harper, A. E. (1959): Amino acid balance and imbalance. Part I. Dietary level of protein and amino acid imbalance. J. Nutr., 68, 405-424.

12) Ebihara, K., Imamura, Y., and Kiriyama, S. (1979): Effect of dietary mineral composition on nutritional equivalency of amino acid mixtures and casein in rats. $J$. Nutr., 109, 2106-2112.

13) Folch, J., Lees, M., and Sloane Stanley, G. H. (1957): A simple method for the isolation and purification of total lipides from animal tissues. J. Biol. Chem. 226, 497-509.

14) Zak, B. (1957): Simple rapid microtechnic for serum total cholesterol. Am. J. Clin. Pathol., 27, 583-588.

15) Burnstein, M., Scholnick, H. R., and Morfin, R. (1970): Rapid method for the isolation of lipoproteins from human serum by precipitation with polyanions. J. Lipid Res., 11, 583-595.

16) Snedecor, G. W., and Cochran, W. G. (1967): Statistical Methods, 6th Ed., Iowa State University Press, Ames, Iowa, (Japanese edition), Chapters 7 and 10.

17) Resources Bureau, Science and Technology Agency of Japan (1966): The Amino Acid Composition of Foods in Japan, Tokyo.

18) Block, R. J., and Weiss, K. W. (1956): Amino Acid Handbook, Charles C. Thomas Publ., Springfield, Illinois, pp. 341-346.

19) Huff, M. W., and Carroll, K. K. (1980): Effects of dietary proteins and amino acid mixtures on plasma cholesterol levels in rabbits. J. Nutr., 110, 1676-1685.

20) Terpstra, A. H. M., Van Tintelen, G., and West, C. E. (1982): The hypocholesterolemic effect of dietary soy protein in rats. J. Nutr., 112, 810-817.

21) West, C. E., Beynen, A. C., Scholtz, K. E., Terpstra, A. H. M., Schutte, J. B., Deuring, K., and .Van Gils, L. G. M. (1984): Treatment of dietary casein with formaldehyde reduces its hypercholesterolemic effect in rabbits. J. Nutr., 114, 17-25.

22) Woodword, C. J. H., and Carroll, K. K. (1985): Digestibilities of casein and soya-bean protein in relation to their effect on serum cholesterol in rabbits. Br. J. Nutr., 54, 
355-366.

23) Yashiro, A., Oda, S., and Sugano, M. (1985): Hypocholesterolemic effect of soybean protein in rats and mice after peptic digestion. J. Nutr., 115, 1325-1336.

24) Van der Meer, R. (1983): Is the hypercholesterolemic effect of dietary casein related to its phosphorylation state ? Atherosclerosis, 49, 339-341.

25) Seidel, J. C., Nath, N., and Harper, A. E. (1960): Diet and chlesterolemia: V. Effect of sulfur-containing amino acid and protein. J. Lipid Res., 1, 474-481.

26) Feland, B., Fuqua, E. G., and Smith, J. T. (1973): Effect of dietary sulfur on serum cholesterol and glycocholic: taurocholic acid ratio of the rat. J. Nutr., 103, 1561-1565.

27) Katan, M. B., Vroomen, L. H. M., and Hermus, R. J. J. (1982): Reduction of caseininduced hypercholesterolemia and atherosclerosis in rabbits and rats by dietary glycine, arginine and alanine. Atherosclerosis, 43, 381-391.

28) Sautier, C., Dieng, K., Flament, C., Doucet, C., Suquet, J. P., and Lemonnier, D. (1983): Effect of whey protein, casein, soya-bean and sunflower proteins on the serum, tissue and faecal steroids in rats. Br. J. Nutr., 49, 313-319.

29) Bigwood, E. J. (1972): Amino acid patterns of animal and vegetable proteins-common features and derivatives, in Protein and Amino Acid Functions, ed. by Bigwood, E. J., Pergamon Press, Oxford, pp. 215-257.

30) Jenkins, M. Y., Mitchell, G. V., and Vanderveen, J. E. (1983): Effect of dietary protein and lecithin on plasma and liver lipids and plasma lipoproteins in rats. Nutr. Rep. Int., 28, 621-634.

31) Jenkins, M. Y., and Mitchell, G. V. (1985): Influence of three dietary sources of choline on liver lipids in rats fed animal or plant protein. Nutr. Res., 5, 473-485. 